Section Editor

Robert C. Griggs, MD
Editors' Note: In response to the defense by Heck et al. of the conservative management of ruptured lenticulostriate artery (LSA) aneurysms, Cai et al. suggest an international, multiple-center registry to better study this condition. Shirota et al. answer some of the points raised by Ramos et al. on transcranial magnetic stimulation (TMS) in Parkinson disease (PD) and agree that their suggestions would improve the quality of future clinical trials.

—Chafic Karam, MD, and Robert C. Griggs, $M D$
PEARLS \& OY-STERS: SMALL BUT CONSEQUENTIAL: INTRACEREBRAL HEMORRHAGE CAUSED BY LENTICULOSTRIATE ARTERY ANEURYSM

Olivier Heck, René Anxionnat, Serge Bracard, Nancy, France: Cai et al. ${ }^{1}$ described a case of ruptured LSA aneurysm treated with surgery after a hemorrhage recurrence. They concluded that urgent treatment was necessary to minimize rebleeding risks.

The surgical or endovascular treatment of these aneurysms is possible but risky as they are located deep in the brain and close to sensitive cerebral tissue. ${ }^{2}$ Very few cases of ruptured LSA aneurysms are reported. Their natural history and specifically the risk of hemorrhage recurrence are unclear. ${ }^{3}$ Several cases of spontaneous involution free of hemorrhage recurrence have been reported. ${ }^{4}$

In our institution, we encountered 3 recent cases of ruptured LSA aneurysms revealed by deep cerebral hematomas and we treated them conservatively. There was no hemorrhage recurrence and follow-up angiography demonstrated spontaneous thrombosis in 2 of the 3 cases.

Our experience, which coincides with past studies, leads us to think that a conservative approach with accompanying angiographic monitoring may be proposed as first-line treatment. If an aneurysm then persists or grows, its occlusion should be considered. Nonetheless, other studies are needed to further strengthen the legitimacy of this strategy.

Author Response: Xuemei Cai, Steve Han, Steven Feske, Sherry Chou, Boston: Heck et al. described 3 patients with ruptured LSA aneurysms revealed by
WriteClick: Editor's Choice

deep cerebral hematomas. They were treated conservatively and did not have subsequent hemorrhage.

In our case report, despite optimal medical therapy including tight blood pressure control, our patient had intracerebral hemorrhage (ICH) expansion. The patient's surgery was performed without complication so both surgically and medically treated cases exist for this rare condition.

We agree with Heck et al. that ICH from this type of aneurysm is so rare that the natural history of this disease is unclear, particularly targeting patients who will go on to have spontaneous thrombosis and those who will rebleed. We both seem to make a good case for an international, multiple-center registry to better study this condition.

LSA aneurysms are easily missed and therefore likely underdiagnosed. Improving our diagnostic accuracy may improve our knowledge about prevalence and natural history of the disease and may improve patient outcomes in the future.

(C) 2013 American Academy of Neurology

1. Cai X, Han S, Feske SK, Chou SH- Y. Pearls \& Oy-sters: Small but consequential: intracerebral hemorrhage caused by lenticulostriate artery aneurysm. Neurology 2013;80:e89-e91.

2. Gandhi CD, Gilad R, Patel AB, Haridas A, Bederson JB. Treatment of ruptured lenticulostriate artery aneurysms. J Neurosurg 2008;109:28-37.

3. Mizutani T, Kojima H, Miki Y. Arterial dissections of penetrating cerebral arteries causing hypertension-induced cerebral hemorrhage. J Neurosurg 2000;93:859-862.

4. Lama S, Dolati P, Sutherland GR. Controversy in the management of lenticulostriate artery dissecting aneurysm: a case report and review of the literature. World Neurosurg Epub 2012 Dec 12.

\section{SUPPLEMENTARY MOTOR AREA STIMULATION FOR PARKINSON DISEASE: A RANDOMIZED CONTROLLED STUDY}

Vesper Fe Marie L. Ramos, Rainer W. Paine, Nivethida Thirugnanasambandam, Bethesda, MD: Shirota et al. ${ }^{1}$ reported a large trial of repetitive TMS of the supplementary motor area (SMA) for PD. Stimulation was given weekly for 8 weeks, with a 3-arm design.

The authors did not report baseline Unified Parkinson's Disease Rating Scale (UPDRS) scores and 


\section{Neurology}

\section{Pearls \& Oy-sters: Small but consequential: Intracerebral hemorrhage caused by lenticulostriate artery aneurysm \\ Olivier Heck, Xuemei Cai, René Anxionnat, et al. \\ Neurology 2013;81;1881 \\ DOI 10.1212/01.wnl.0000435757.50996.ae}

This information is current as of November 18, 2013

Updated Information \& Services

References

Permissions \& Licensing

Reprints including high resolution figures, can be found at: http://n.neurology.org/content/81/21/1881.1.full

This article cites 3 articles, 1 of which you can access for free at: http://n.neurology.org/content/81/21/1881.1.full\#ref-list-1

Information about reproducing this article in parts (figures,tables) or in its entirety can be found online at:

http://www.neurology.org/about/about_the_journal\#permissions

Information about ordering reprints can be found online:

http://n.neurology.org/subscribers/advertise

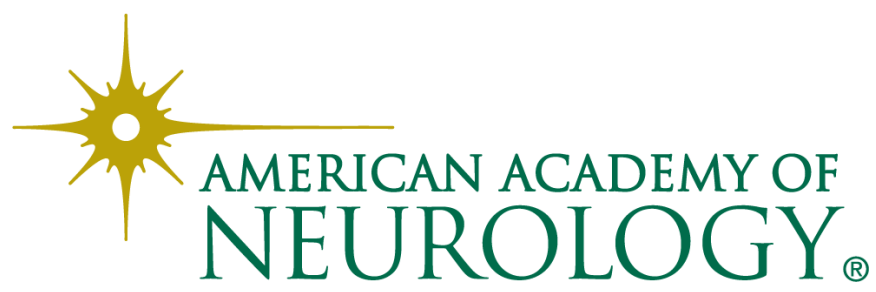

